\title{
World-wide trends in powertrain system development in light of emissions legislation, fuels, lubricants, and test methods
}

Both the light- and heavy-duty sectors of the automotive industry are currently under unprecedented pressure from a wide range of factors, particularly in terms of environmental performance and fuel consumption. Test procedures have undergone massive changes and continue to evolve, meaning that standards are becoming much harder to meet, especially in Europe but also in other continents. Such developments force changes in testing methodology, the development of powertrains themselves and their aftertreatment systems and strategies and calibrations. This paper reports and summarises the topics of the PTNSS Congress and attempts a synthesis on the current status of the field of LD ad HD IC engines, hybrid powertrains and electric vehicles, engine fuel and oil and what the coming years may hold for the automotive and fuel industries and other allied fields.

Key words: global LD/HD exhaust emissions, powertrain development, LD and HD IC engines, test methods, fuel development

\section{Introduction}

It is widely expected that the next 20-30 years will be characterized by a high increase in the global population, especially in developing countries, with growth in the global economy and increasing urbanization. The global population is expected to increase from 7.6 to 9.2 billion by 2040 . Global GDP will likely double over the same period, and several billion people are expected to join the middle class, despite unpredictable adverse events such as the Covid-19 pandemic. The expected increase in the concentration of human population in big cities worldwide will generate incremental demand for new infrastructure, distribution services for goods and local and regional transport (public as well as private): light-duty and heavy-duty vehicles (LDV and HDV) [1]. New gas, electric and hydrogen refuelling and charging stations, as well as other infrastructure, will have to be constructed to meet these needs, together with new roads, parking places and better road traffic organization, since the current vehicle fleet may even double in size over the next 30 years (or so) [2]. This will increase demand for liquid and gaseous fuels, alternative and e-fuels, electricity and hydrogen, to be met via increased production $[3,4]$.

Among the drivers influencing vehicular and non-road mobile machinery (NRMM) powertrain development, the field of greenhouse gases (GHG) and exhaust emissions is experiencing wide-ranging and rapid changes [4]. New emissions regulations such as Euro 6d for LDV and new test methods (RDE and WLTP) as well as Euro VI D and planned Euro VI E for HDV and the future Euro 7/VII standards are the main challenges for the automotive and powertrain industry, caused by political, socioeconomic and technical factors [5]. Air quality is very high on the political agenda and pressure remains to limit and reduce greenhouse gas emissions from the road transport sector. In addition to limits becoming increasingly stringent, the list of parameters subject to legal limits is slowly expanding and, most importantly, these limits must be met under a wide range of conditions [6].

Discussion of GHG emissions, as well as emissions of pollutants such as $\mathrm{NO}_{\mathrm{x}}$ and particulates - and methods to reduce such emissions, are currently underway in all the main automotive markets, as well as at the forum of UNECE GRPE Group - the World Forum for Harmonization of Vehicle Regulations [6-8]. One of important problems occurring in this area in the EU during vehicle Type Approval (TA) tests are the differences in the results of measurements of $\mathrm{CO}_{2}$ emissions in TA tests performed using the NEDC cycle and under real driving conditions, as well as the methods of compensating for these differences after the alteration of the test procedure via the introduction of the WLTP [9, 10].

The PMP (Particulate Measurement Programme), a subgroup of UNECE GRPE, is working on a new methodology for measurements of PM/PN emissions and on the extension of the testing methodology of the number of nanoparticles (PN) for the current cut-off point of $23 \mathrm{~nm}$ down to $10 \mathrm{~nm}$, to assess the emission of these particles which are currently not subject to limitation, which is significant especially in the case of gasoline and gaseousfuelled engines [11-14]. The PMP team is also working on the introduction of methods testing and measuring the emission of particles generated from brake discs and brake pads used in road vehicles and the planned work for new emission standards at the post-Euro 6/VI level [15].

Fossil fuels used in the transportation sector affect Earth's climate negatively due to $\mathrm{CO}_{2}$ emissions. Implementation of sustainable and renewable fuels for transportation has become a very important step in the reduction of the sector's carbon footprint. An effective solution for GHG reduction is the substitution of fossil fuels used in the current fleet by fuels produced from renewable sources such as biofuels, but also e-fuels and low-carbon (or even carbonfree) fuels, mainly hydrogen $[16,17]$.

A range of strategies are available to overcome these difficulties, as explored during the VIII International Congress on Combustion Engines organised by the Polish Scientific Society of Combustion Engines (PTNSS) and hosted at Krakow University of Technology, Poland in June 2019.

As it was presented during previous PTNSS Congresses [18] as well as International Exhaust Emissions Symposia (IEES) co-organized by BOSMAL and PTNSS [19, 20], the 
content of the VIII International PTNSS Congress on Internal Combustion Engines included new developments in the field of design, testing, manufacturing and maintenance of internal combustion engines for LD and HD vehicles and NRMM, hybrid and electric powertrains as well as fuel-cell development. Development of new sustainable fuel and biofuels and engine oils with low friction characteristics was also covered, as well as discussions of GHG emissions reduction efforts' influence on powertrain technology and all environmental-related issues, such as new rules and test methods, new parameters to be tested and new emissions limits.

\section{Organisation of the VIII PTNSS Congress}

During the years 2005-2017, the Polish Scientific Society of Combustion Engines (hereafter PTNSS), organised seven International Congresses on combustion engines, covering issues related to limiting emission of harmful exhaust emissions from automotive sources and their impact on the development of vehicle powertrain design, the development of fuel technology, engine oils, exhaust gas treatment systems and new research methods, as this subject is vitally important for the further development of the motor industry globally, in Europe generally and of course also in Poland. These Congresses were very popular among professionals in the automotive and fuel industries, both foreign and domestic, who participated extensively in their deliberations.

On $17^{\text {th }}-18^{\text {th }}$ June 2019 , PTNSS, in cooperation with the Institute of Automobiles and Combustion Engines from Cracow University of Technology organized the VIII International Congress on Combustion Engines. VIII International Congress on Combustion Engines was held at Cracow University of Technology, at its campus on ulica Warszawska in Krakow. Other institutions were also involved in the organization of this event, such as Poznan University of Technology and BOSMAL Automotive Research and Development Institute.

The Congress covered a wide range of topics in the research fields mentioned earlier, which were explored by specialists from all over the world. The Congress also covered varied applications of combustion engines, including aviation and marine engines. It was a meeting with expert engineers and researchers sharing their new ideas, inventions, and experience. Attendees had the opportunity to add to their knowledge on a wide variety of subjects related to combustion engines and were able to enjoy, along with colleagues, friends and family, the warm welcome and hospitality afforded by the city of Krakow.

The main themes of the Congress were:

- Engine development - all engine types/sizes,

- Fuel injection systems and mixture formation,

- Combustion processes control in SI and CI engines,

- Engine thermal loading and utilization of heat released,

- Alternative fuels,

- Emission measurements and aftertreatment,

- Alternative sources of power,

- Engine testing, durability, reliability and diagnostics,

- Modelling and optimization of engine processes,

- Global trends in engine technology,

- Hybrid and electric powertrains,
- Fuels and engine oil development.

An important goal of this Congress was also the integration of the scientific and academic communities with the automotive industry (both in Poland and abroad), facilitating the establishment of new contacts, the exchange of knowledge on many issues, as well as promoting the achievements of Polish scientific and research institutions active in the fields mentioned above.

Around 200 delegates participated in the event, representing automotive and fuel industry companies, the European Commission (the EC JRC Ispra Research Centre), a key US Government Research Center (Argonne National Laboratory near Chicago), research institutes and industrial research centres from the automotive and fuel industries, and an international academic community from 16 countries (USA, Japan, China, Brazil, UK, Spain, Italy, Switzerland, Austria, Germany, Finland, France, Slovakia, Lithuania, Ukraine and Poland) representing 4 continents (Europe, North America, South America, Asia). The final programme (http://www.congress.ptnss.pl/kongres/5/final-programme) contains details of all technical presentations and other information on the event.

The VIII Congress was formally opened by Prof. Jerzy Merkisz (PTNSS, Poznan University of Technology), acting in his capacity of PTNSS president. Participants were also welcomed by Prof. Marek Brzezanski on behalf of the main Congress organizer: the Institute of Automobiles and Combustion Engines from Cracow University of Technology in Cracow, Poland.

Twenty five invited presentations were delivered during Plenary Sessions of the Congress by well-known experts on Combustion engines and powertrain system development, emissions of harmful exhausts from motor vehicles, fuels and engine oils and development of engine/vehicle testing methods. The programme for the Plenary Sessions was organised and prepared by Dr Piotr Bielaczyc and BOSMAL Automotive Research and Development Institute Ltd, Bielsko-Biala, Poland, who were involved in securing invited speakers for the Congress and preparation of the technical programme.

Presentations were delivered during five plenary sessions covering various issues of powertrain and fuel development, with the following titles:

1. Global LDV/HD exhaust emissions development.

2. Powertrain technology development (light -duty).

3. Powertrain technology development (heavy-duty \& NRMM).

4. Fuel development and its impact on engine technology.

5. Testing requirements/methodologies - impact on powertrain development.

Individual sessions were chaired by well-known powertrain research experts from Poland and abroad: Les Hill (Horiba, UK), Piotr Bielaczyc (BOSMAL, Poland), Luciano Rolando (Politecnico di Torino, Italy), Andrzej Teodorczyk (WUT, Poland), Adolfo Perujo (JRC, Italy), Miroslaw Wendeker (LUT, Poland), Christopher Kolodziej (ANL, USA), Krzysztof Wislocki (PUT, Poland), David Miller (3DATX, USA) and Pawel Fuc (PUT, Poland).

In addition to the plenary presentations, around 150 technical papers that were accepted for the Congress were 
published in successive issues of this journal in 2019 and 2020.

The Congress was sponsored by BOSMAL \& Borg Warner (Gold Sponsors), AVL, Horiba \& LaVision (Silver Sponsors), 3DATX, Air Liquide, Biuro Inzynierskie M. Zajaczkowski \& Motor Transport Institute (Sponsors). This journal, published by PTNSS, provided the official media patronage for the event.

More information about the congress and its organization, including the full programme, can be found at: http://www.congress.ptnss.pl/kongres/5/.

\section{Congress sessions and their content}

\section{1. $1^{\text {st }}$ session - Global LDV/HD exhaust emissions development}

The first session's content related to general aspects of vehicular exhaust emissions and global standards for their reduction.

The discussions during this first session included the new method for measuring emissions under real road driving conditions - RDE, as well as the newly-introduced chassis dynamometer procedure (WLTP) described in UNECE Regulation GTR 15 and mandated in EU legislation, thus replacing the NEDC cycle which had been in use in the EU since 2000. A comparison of emissions standards in the EU, USA, China, Japan, and India was presented. Global trends in reducing emissions from vehicles using the example of the European Union, Japan, USA, China and India were also discussed, as well as the main features of new EU emission standards developed by the GRPE (UNECE) and RDE groups, which were introduced into the EU approval requirements as the emission level Euro 6d TEMP from 1st September 2017, through Commission Regulations (EU) 2017/1151 and 2017/1154.

Les Hill (Horiba, UK) presented trends on reducing emissions on a global scale as well as their impact on measurement procedures and the requirements for test equipment and test methods. The US has introduced EPA Tier 3 and CARB LEV-III (in California) requirements, as well as regulations on GHG emissions, with procedures defined in CFR part 1065 and part 1066, which are still being continually updated.

Japan plans to introduce testing methods based on the WLTP procedure (3-phase test, without driving speeds $>100 \mathrm{~km} / \mathrm{h}$ ) and RDE tests for vehicles with CI engines. China and India likewise plan to introduce similar standards as in the EU, based on WLTP tests and methodology, and also RDE in the future. Thus, the precedent for RDE testing to expand from its point of origin (the EU) to other legal jurisdictions over the next few years appears clear; particularly significant are the plans for introduction of rigorous $\mathrm{RDE}$ requirements by the large (and growing) markets of China and India. The formation of a new UNECE Informal Working Group for Global RDE reflects this situation [21].

The second presentation on this subject was delivered by Dr. Piotr Bielaczyc (BOSMAL, Poland), who presented the most important technical, political and economic factors that currently affect the development of global road transport and propulsion system used, and current "hot topics" in powertrain development. Dr. Bielaczyc's presen- tation also highlighted the impact of new emission testing methods on the development of automotive engine structures and future trends in vehicular powertrains [22, 23]. His presentation examined the current situation regarding regulation of exhaust emissions and the impact on powertrains used in new vehicles across the world. Powertrain technologies which can help to overcome challenges are mentioned and key trends were analysed. Despite Diesel engines' loss of reputation according to some commentators, manufacturers of these engines have already implemented solutions based on SCR catalytic systems, together with existing filtration technology, which can ensure that this engine type has very low emissions of both PM/PN and $\mathrm{NO}_{\mathrm{x}}$. A new trend in engine design is "rightsizing", as well as an ongoing convergence of spark ignition and compression ignition engine technology, with differences now much smaller than in the past (turbocharging, direct injection, compression ratio) - see Fig. 1. Fundamental changes to the propulsion strategy for on-road vehicles, most notably (but not exclusively) hybrids of various types, and the development of fully electric vehicles (BEV) or fuel cell-powered vehicles represent a revolution in the industry, occurring in the context of the aforementioned effects. As development requirements are more complex than in the past and the test volume is also much higher, the challenges posed in developing, testing, approving and certifying such advanced solutions is considerable [24].

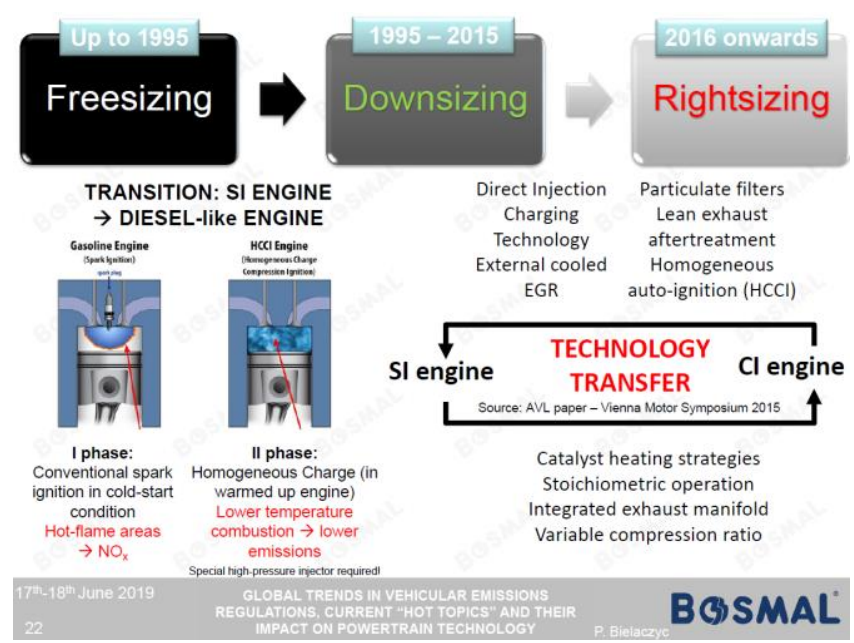

Fig. 1. Overview of engine technology trends, including the ongoing gradual convergence of SI and CI engines [24]

In the first session, which was devoted to the global regulations and methods of emission testing in the context of combustion engines, further reports were presented by Dr. Victor Valverde-Morales (European Commission, JRC) who presented the issues of air protection against pollution from automotive sources in the European Union (EU Clean air policy) and the latest data on the implementation of WLTP and RDE regulations in the European Union as tools to meet those aims, as well as market surveillance of the vehicle fleet from 2020. Recent activities on light-duty vehicles' pollutant emissions in the EU are the following:

- Amended Emissions Legislation at EU level. 
- New/revised emission testing procedures: Worldwide harmonized Light vehicles Test Procedures (WLTP), Real Driving Emissions (RDE) regulation.

- In-Service Conformity (ISC) provisions.

- New type approval and market surveillance regulation adopted in 2018, in force from 2020.

Subsequent changes in research procedures will result in the fourth RDE package, which will also introduce tests of cars in use, to be performed by independent accredited laboratories as well as vehicle manufacturers. The analysis of the next emission regulations, described as 'post-Euro 6' - and even 'Euro 7' - has begun, which are to bring the same test methods and limits for all types of engines and fuels (a philosophy known as 'fuel-neutral' or 'technologyneutral', which has already been in place in the USA for many years) [25].

The last presentation in this session was delivered by Dr. Ameya Joshi (Corning Inc., USA), who spoke about the methods for limiting engine emissions from LDV and HDV through catalytic systems, also for hybrid powertrains in which the TWC and other catalytic reactors may undergo cooling when the combustion engine is not running. He also talked about the possibilities of increasing the efficiency of engines used in road transport. Thermal efficiency of $45 \%$ has already been achieved for SI engines, but further development in this field is still possible (see Fig. 2) - currently a level of $55 \%$ for the CI engines used in HD applications is being worked on. A significant part of his presentation was devoted to catalytic aftertreatment (SCR, SCRF, PNA, methane oxidation catalysts) as well as multi-component systems consisting of catalytic reactors and filters, which can allow engines to meet legal emissions requirements under a wide range of operating conditions [26]. The main conclusions from his presentations are the following.

Key summary points regarding light-duty vehicles:

- Europe has set the tightest $\mathrm{CO}_{2}$ standards: $37.5 \%$ reduction by 2030 , along with electrification mandates.

- There is still significant untapped potential for ICE technologies. Much more efficiency improvements to come. Synergistic gains with hybridization lie ahead (see Fig. 2).

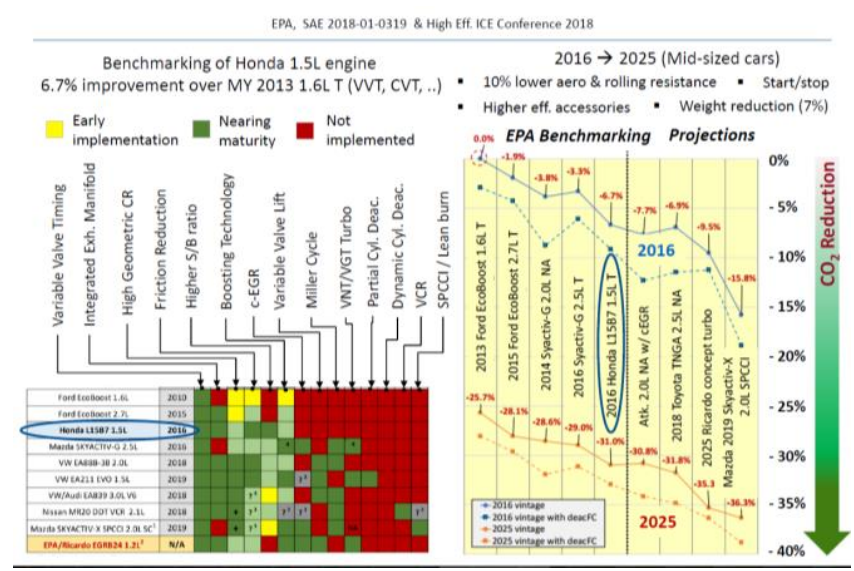

Fig. 2. Engine technology options for increased efficiency and reduced emissions [27]
- Both gasoline \& diesels can comfortably meet Euro 6 norms. The path to $\mathrm{NO}_{\mathrm{x}}$ at a level of $<10 \mathrm{mg} / \mathrm{km}$ has been shown for diesels.

- Gasoline particulate filters are being deployed in the EU/China. PFI and hybrids may also require GPFs.

- Addressing cold start emissions is critical to meet the US SULEV30 standard. TWCs continue to improve, but may require addition of $\mathrm{HC}$ traps.

Key summary points regarding heavy-duty vehicles:

- California is leading the development of an omnibus rule for lower in-use $\mathrm{NO}_{\mathrm{x}}$ emissions. Various studies on evaluation technology options reviewed.

- Europe has established its first-ever $\mathrm{HD} \mathrm{CO}_{2}$ standards: $30 \%$ reduction required by 2030, compared to 2019 .

- Super Truck II program (participants: Volvo, Navistar, Cummins, Daimler) is promising impressive gains in fuel efficiency - leading concepts were reviewed.

- Several filter-enforcing regulations in place: China VI, BS VI, non-road Tier 4, Brazil PROCONVE P8 [27].

\section{2. $2^{\text {nd }}$ session - Powertrain technology development - light-duty}

Prof. Jerzy Merkisz from Poznan University of Technology (Poland) commenced the second session on lightduty powertrain developments with a broad yet detailed overview of the subject. To meet the goal of reducing tailpipe $\mathrm{CO}_{2}$ by $90 \%$ by 2050 , it was projected that post-2020, powertrain developments will focus heavily on electrification (hybrids to pure battery electric vehicles), as shown in Fig. 3.

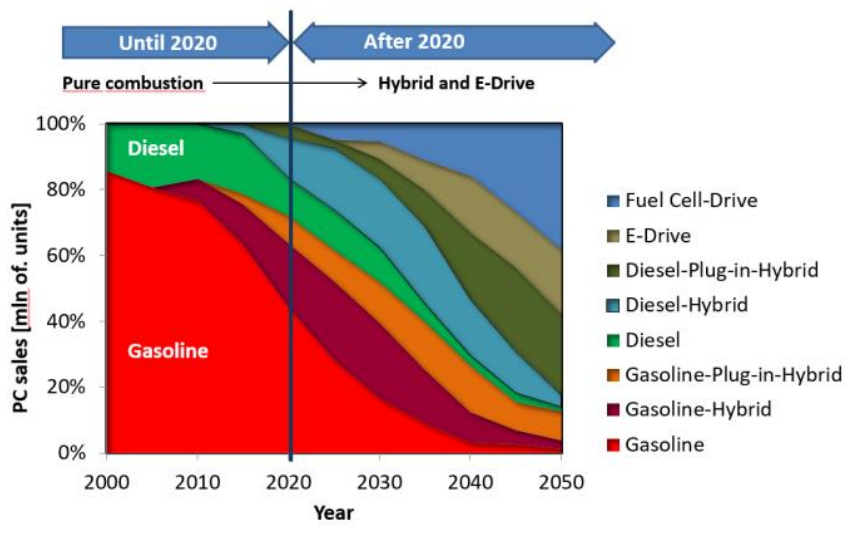

Fig. 3. Market share of various powertrains projected to 2050 [28]

However, it was cautioned that for a realistic assessment of the benefits of electrification, it is imperative for well-towheel emissions to be included, which can increase the tank-to-wheel emissions by as much as $30 \%$. ICE developments will continue, and several promising technologies were reviewed. Engine downsizing is approaching its limit, and now emphasis is turning to "rightsizing" to balance efficiency and performance requirements. Recently developed advanced engine technologies are expected to proliferate, including variable compression ratio (VCR), water injection and spark assisted charge compression ignition for gasoline engines. The increased use of mild hybridization, turbocharging, exhaust gas recirculation (EGR) and optimized aftertreatment systems including filters is a common 
theme for both gasoline and diesel. Several new engines have been announced by major OEMs recently aimed at meeting Euro 6d emission legislation, improved fuel economy, while also meeting the core customer requirements of improved power and dynamic handling. Diesels continue to improve (i.e. lower) tailpipe $\mathrm{NO}_{\mathrm{x}}$ emissions using SCRcoated filters, although meeting future requirements will require further reduction of cold start emissions via the addition of close-coupled lean $\mathrm{NO}_{\mathrm{x}}$ traps, passive $\mathrm{NO}_{\mathrm{x}}$ adsorbers or electrically heated catalysts [28].

Dr. Hubert Friedl (AVL List, Austria) highlighted various technologies which need to be developed and adopted to approach near-zero emission levels. A few examples include particulate filters for all vehicles, $\mathrm{NO}_{\mathrm{x}}$ storage catalysts, passive SCR, electrically heated catalysts, predictive control strategies and electric drive-off. Improving battery technology is projected to reduce the cost differential between pure electric and conventional ICE powertrains by $>60 \%$ in the 2020-2025 timeframe, as shown in Fig. 4.

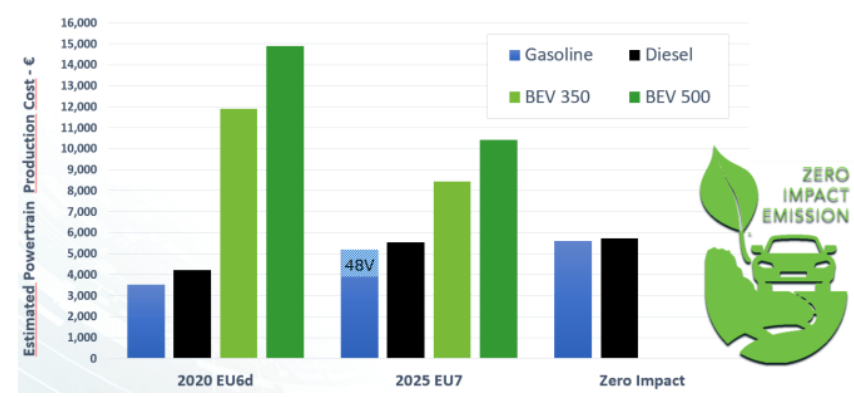

Fig. 4. Estimated production costs (in Euros) for gasoline, diesel and battery electric powertrains [29]

Nevertheless, ICEs and hybrids are expected to dominate, with $48 \mathrm{~V}$ mild hybrids projected to gain up to $68 \%$ market share in Europe by 2030. Brake thermal efficiencies up to $50 \%$ are now within sight, relying on various advanced gasoline technologies such as very high pressure (> 1000 bar) injection, pre-chamber ignition, VCR, ultralean $(\lambda>2)$ combustion and waste heat recovery, as outlined in Fig. 5 [29].

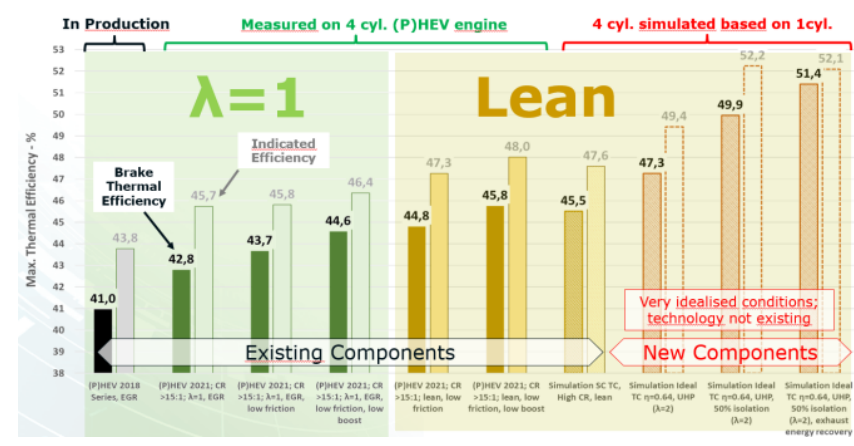

Fig. 5. Efficiency projections of a hybrid 4-cyliner engine using existing and future technologies [29]

Emissions legislation in Europe have undergone a fundamental shift since the introduction of the real-world driving emission (RDE) testing. In the presentation by Dr. Friedl and in another presentation by fellow AVL employee Kurt Engeljehringer, it was pointed out that the requirement for RDE and lower temperature $\left(-7^{\circ} \mathrm{C}\right)$ testing has resulted (or will soon result) in $>7$-fold increase in the testing time for certification, compared to pre-Euro 6 standards. Further tightening is widely expected with post Euro 6 regulations, including increasing the weighting for cold start and urban driving via shortening the urban portion of the RDE test. The utility of bringing road testing as required by RDE "back to the lab" was highlighted as a way to enhance reproducibility, perform detailed tests not possible on the road, and better analyse the influence of various parameters [30].

Steve Whelan (Horiba-Mira, UK) expanded on this idea, by discussing their work done on an integrated "RDE+ Road to rig approach" for powertrain testing and development. One gasoline and two diesel vehicles were tested over four RDE routes characterized by varying driving dynamics, and temperature and altitude boundary conditions. As expected, the $\mathrm{CO}_{2}$ and $\mathrm{NO}_{\mathrm{x}}$ emissions were sensitive to these conditions, although the testing showed some non-intuitive results such as higher $\mathrm{NO}_{\mathrm{x}}$ emissions with gentler driving, hypothesized due to catalyst light-out under these conditions. The route was next replicated on a chassis dynamometer using the gasoline vehicle. A very good correlation for RDE and chassis testing was achieved for all criteria pollutant and $\mathrm{CO}_{2}$ emissions (all within 10\%) [31]. This early work promises to deliver expedited development and evaluation of the impact of various real-world driving scenarios in a lab environment at a faster pace [32].

While significant improvements are being made to lowering criteria pollutants and meeting the post Euro 6 regulations, there are unique challenges that still need to be addressed. A decrease in engine-out $\mathrm{NO}_{\mathrm{x}}$ can lead to an increase in soot emissions due to the soot- $\mathrm{NO}_{\mathrm{x}}$ trade-off. Marcos Alonso Baez (Nissan Technical Centre, Spain) discussed the contamination of oil with such an increase in soot and its root cause. CFD modelling was used to predict the combustion, the associated emissions of soot, and its transport from the hot combustion gas to the cold cylinder walls due to thermophoretic force. Higher soot in oil were found with increased EGR and lower injection pressures, while retarding start of injection was found to lower the soot amount. Broadly, good correlation was found between predicted trends and measured values for soot in oil, although there is room for improvement in absolute soot quantity estimations [33].

As mentioned in the opening presentation of this session, $48 \mathrm{~V}$ mild hybrids are expected to gain a significant market share in the coming years. Dr. Luciano Rolando (Politecnico di Torino, Italy) and discussed the potential of electric supercharging (eSC) for performance and fuel efficiency improvements of gasoline engines, when coupled with mild hybridization and Miller cycle combustion. Simulations were done for a SUV with $1.5 \mathrm{dm}^{3}$ turbocharged gasoline engine with a $48 \mathrm{~V}$ P0 architecture. The transient performance with the $\mathrm{eSC}$ was evaluated for accelerating from 80 to $120 \mathrm{~km} / \mathrm{h}$ and 60 to $80 \mathrm{~km} / \mathrm{h}$. The eSC compensates for the engine turbo lag and improves elasticity time. While there is a small energy consumption penalty (equivalent to $2-3 \mathrm{gCO}_{2} / \mathrm{km}$ ), when the described solution was combined with the Miller cycle, a net reduction of $\mathrm{CO}_{2}$ by $6 \mathrm{~g} / \mathrm{km}$ was obtained (via simulation) over the entire WLTC [34]. 


\section{$3.33^{\text {rd }}$ session - Powertrain technology development - heavy-duty}

This session mirrored the previous session, but with a specific focus on heavy-duty and NRMM.

Dr. Adolfo Perujo (EC JRC, Italy) spoke about field testing of various vehicles and pieces of machinery in the context of demonstration of compliance with EU emissions legislation. In the EU, emissions from light-duty, heavyduty and NRMM applications (the latter not consisting of vehicles) have a long history of regulation. Changes are underway in emissions legislation for all three groups, with a strong trend towards lower limits and stricter demonstrations of compliance. On-road heavy-duty and NRMM share certain similarities, but also fundamentally different in some respects and are this dealt with in separate legislation. The European Commission's Energy, Transport \& Climate directorate has been working on the steps necessary to update, expand and strengthen the aforementioned legislation. NRMM is a very broad category, with applications featuring combustion engines of power ranging from less than 10 $\mathrm{kW}$ to approaching $1 \mathrm{MW}$ (i.e. a variation by a factor approaching 100); see Fig. 6. Applications may or may not be self-propelled (saws, cement mixers, etc. being essentially stationary; excavators, trains, boats and snowmobiles selfevidently being fully mobile). Overall, the EU strives for alignment with US EPA standards, but some PM standards are more demanding and PN represents a much more demanding requirement (no US emissions legislation currently requires any kind of particle number measurement). Furthermore, alignment with EU on-road emissions limits is also a goal for NRMM legislation. An example of such alignment is introduction of PN limits for NRMM in legislation passed in 2016. For the time being, limits are determined by engine type (compression/spark ignition) and fuel-neutral limits for NRMM seem a distant prospect. As regards in-use emissions, requirements for NRMM have been built upon the requirements for on-road heavy-duty ISC - legislation passed in 2016 requires in service monitoring (ISM) for emissions from NRMM engines when mounted in target applications tested under normal conditions of use. For NRMM, "normal conditions of use" is a broad and therefore challenging set of circumstances and conditions. Differences in usage patterns (for example, extended idling for NRMM) means that the mandatory PEMS-based emissions monitoring methods are not identical for HD and NRMM [35].

Turning to pollutant formation within the context of detailed investigations into combustion, Dr. Yuzo Aoyagi (Okayama University/New A.C.E. Institute Co. Ltd., Japan) spoke about how investigations into combustion and pollutant formation must present more information than only concentrations of pollutants in the exhaust gas. Fortunately, some well-established methods are available which provide a great deal of information on combustion and pollution formation phenomena. By combining the powerful twocolour method with further optical measurements, insight can be gained into one of the fundamental disadvantages of the Diesel engine: the $\mathrm{PM}-\mathrm{NO}_{\mathrm{x}}$ trade-off [36]. Aftertreatment notwithstanding, there is pressure to reduce engineout concentrations of these pollutants, but the difficulty of optimising such a classic trade-off relationship is well known. High-resolution insights into soot formation and incylinder destruction and spatial distribution, as well as the thermal evolution of the mixture can provide information on the root causes of formation of these pollutants and evaluate efforts to mitigate formation (including, but by no means limited to, the use of EGR and the impact of varying fuel injection parameters) [37].

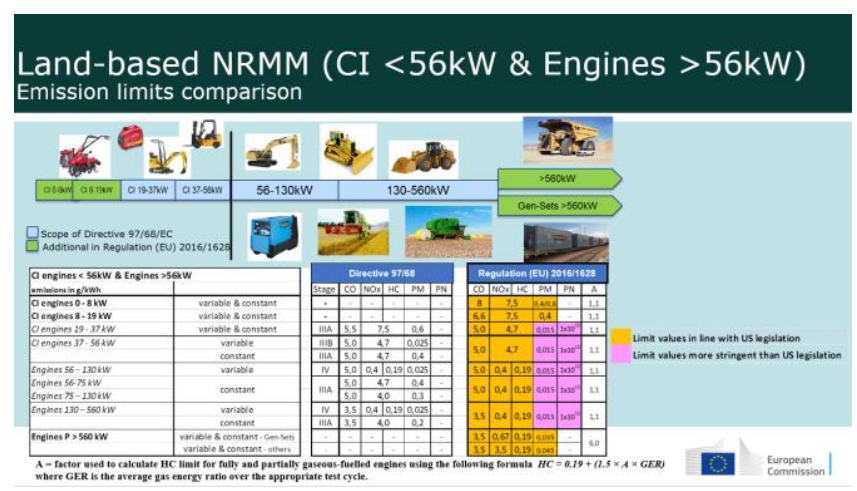

Fig. 6. Outline of the legislative structure for setting emissions control for land-based NRMM, with emissions limits [35]

Prof. Kohei Nakashima (Meijo University, Japan) reported on a concrete aspect of efforts to reduce fuel consumption. Work to reduce fuel consumption has focused on many areas on the powertrain system, as well as the wider vehicle. So-called "mileage competitions", in which teams compete to obtain the best fuel economy results, are examples of situations in which both vehicle and engine parameters are optimised to produce very low fuel consumption (and thus high mileage). However, certain physical boundaries represent challenges which are hard to overcome. One such limitation is the inherent internal friction in a reciprocating engine. Indeed, the piston assembly is the greatest single contributor to internal engine friction. Since the points of contact between the piston assembly and the cylinder liner (i.e. the piston rings) are the sources of this friction, friction reduction studies often replace three-ring piston assemblies with two-ring (or even one-ring) versions, yet data is lacking on the exact frictional impact of such a substitution. Experimental apparatus developed to measure the resistive forces in the piston assembly was used to investigate various piston ring assemblies (with one, two or three rings) at engine speeds ranging from 800 to $1600 \mathrm{rpm}$ and three different oil temperatures - the results of one such measurement are shown in Fig. 7. Significantly, measured piston assembly friction was angle-resolved for full rotation of the crank. Overall, the results indicated that the singlering assembly caused the lowest friction at all oil temperatures where engine speed was $\leq 1200 \mathrm{rpm}$; whereas at higher temperature $\left(80^{\circ} \mathrm{C}\right)$ and engine speeds $\geq 1400 \mathrm{rpm}$, friction was lowest with a two-ring assembly (with the top and oil ring installed). Thus, there was no configuration which gave the lowest friction at all engine speeds and all temperatures, highlighting the complexity of the task of reducing fuel consumption via reductions in engine friction [38].

As well as changes to vehicle and engine parameters, a promising direction for emissions reduction (including 
reduced $\mathrm{CO}_{2}$ ) is the use of natural gas as a fuel, as highlighted by Dr. Stefano Golini (CNH Industrial, Italy) in his presentation. FPT Industrial has a long history of offering CNG versions of its heavy-duty powertrains designed for

Effect of absence of oil ring on piston assembly friction $\left(40^{\circ} \mathrm{C}\right.$ and $\left.1000 \mathrm{rpm}\right)$

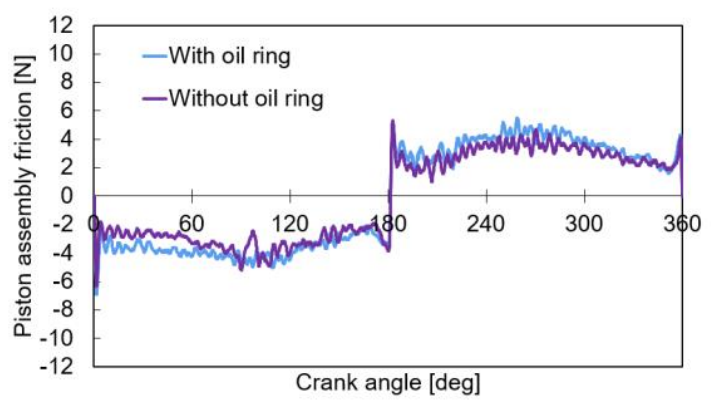

Fig. 7. Crank-angle resolved piston assembly friction for two different piston configurations under low-speed steady state operating conditions [38]

on-road use. CNG is an attractive fuel for a range of reasons, including its low carbon content and soot-free combustion. Furthermore, natural gas (or biomethane) can be obtained from a range of sources, including renewable sources and as such, the potential for GHG emissions reductions can be very high. Heavy-duty vehicles running on CNG have been in use for around 20 years and generally speaking modern CNG-powered engines have comparable performance and durability to their Diesel-powered counterparts. The low energy density of $\mathrm{CNG}$ is an inherent disadvantage, but the CNG distribution network is more extensive than often thought and continues to expand. Vehicle size and weight are the main determinants of the most appropriate energy source (fuel type), as shown in Fig. 8.

\section{NATURAL GAS AS A ROUTE TO DE-CARBONISATION}

ONLY VIABLE ALTERNATIVE TO DIESEL FUEL AVALLABLE TODAY FOR EVERY KIND OF ENERGY DEMAND AND VEHICLE SIZE

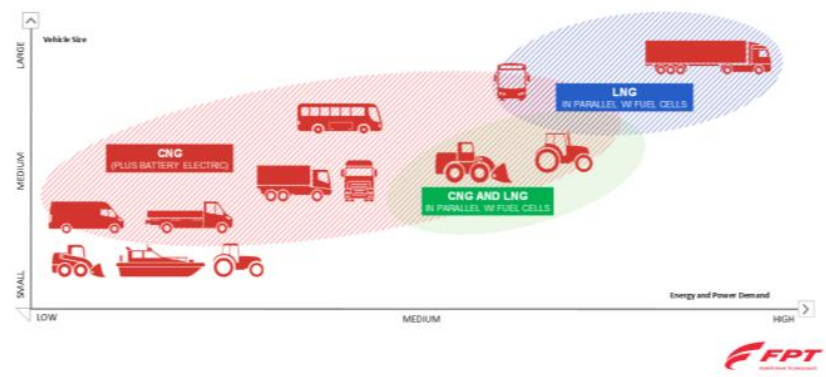

Fig. 8. Schematic of the relationship between vehicle size, energy demand and broad categories of most appropriate fuel type [39]

For large and heavy applications with high energy demand, it is normally more appropriate to store natural gas onboard in the liquid form (LNG). Both CNG and LNG can be used in concert with other technologies for emissions reduction such as fuel cells and externally chargeable hybrid powertrains. Modern HD NG engines offered by FPT achieve Diesel-like performance and high efficiency thanks to several innovative features, including direct injection of natural gas, a specially designed piston and intake system and variable valve timing. Efficiency with these innovations was found to increase by $4 \%$ compared to the previous generation - and at some operating points, thermal efficiency exceeded $40 \%$. In light of these encouraging results, CNG appears to be a viable tool to facilitate ongoing efforts to reduce harmful emissions and GHG emissions from the HD sector. Restrictions or outright bans on Dieselpowered vehicles in some areas (for example: in city centres, port areas or national parks) may make NG-powered vehicles an especially attractive option in some contexts [39].

NRMM As mentioned previously, many industry segments share certain challenges in terms of emissions control; nevertheless, there are sector-specific challenges and limitations. This was explained during the presentation focussing on the sector delivered by Dr. Toni Kinnunen (Proventia, Finland). NRMM is (or will soon be) subject to stricter emissions limits - for example, Stage 5 limits in the EU. There is now also a focus on achieving low real-world emissions from NRMM; the EU is introducing in-service monitoring (ISM) making use of PEMS measurements. An essential tool in efforts to reduce emissions (in general and especially to comply with the aforementioned legislation) from such applications is appropriate aftertreatment. NRMM applications are dominated by compression ignition engines (although spark ignition engines are sometimes used) and as such have certain traits in common with onroad heavy-duty applications. However, there are a number of constraints, difficulties and challenges which are specific to NRMM. These constraints are, for the most part, relate to fundamental design parameters of such applications (length, engine location) and the needs for machinery to move and operate in highly demanding environments (aftertreatment cannot be exposed in vulnerable locations, for example: underneath the chassis). Such constraints, difficulties and specific challenges are summarised in Fig. 9.

\section{Key factors in optimizing EATS for NRMM}

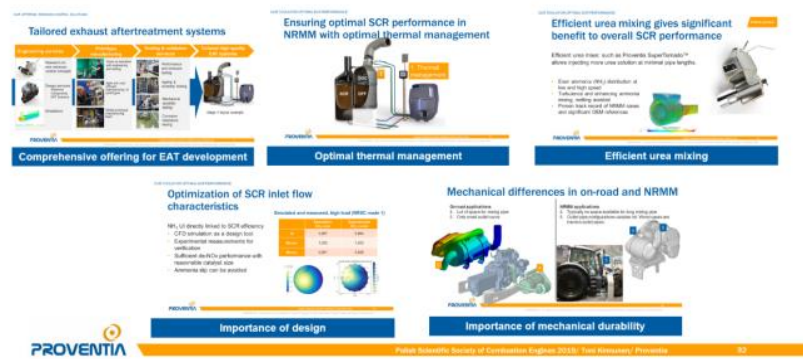

Fig. 9. Key technical factors determining design of exhaust aftertreatment systems in the NRMM sector [40]

In order to achieve truly low emissions under real-world operating conditions, compression ignition engines fitted to NRMM require an integrated DOC + SCR system (sometimes with a DPF), with all relevant mechanical and thermal conditions considered in the design process. As is well known, SCR requires space for the UWS to mix and react and this is very challenging where the layout precludes the installation of extended sections of straight tubing. UWS wall wetting and urea deposit formation are challenges that result from this constraint. The relatively low exhaust gas 
temperatures and extended periods of idling experienced by NRMM mean that thermal management is an important issue. Testing has revealed that NRMM aftertreatment systems are ideal candidates for thermal coatings, which can reduce heat losses by up to $67 \%$ compared to an uncoated system, thereby increasing the efficiency of the SCR and reducing the need for fuel-consuming warm-up strategies. The high amplitude vibrations encountered in off-road environments (up to 100 times higher than for road vehicles) must also be considered in the design process - this fundamental difference is one of the many reasons why bespoke solutions are required [40].

For low fuel/energy consumption and low exhaust emissions under real-world conditions, a huge number of factors must be considered, including - but also extending well beyond - the performance of the internal combustion engine itself. Dr. Joachim Deppe of LaVision (Germany) explained the nature of these challenges and how they can be approached in his wide-ranging presentation. The ability of systems to work in tandem with the powertrain from the chemical and physical points of view is an aspect which must be given careful consideration. More holistically, a number of components which are not part of the engine system must be carefully considered in the context of ongoing efforts to reduce vehicle mass, rolling resistance, aerodynamic resistance, etc. - potentially including myriad components, from bearings to tyres to window glass. These materials' optimisation challenges must be informed by quantitative data, with a range of tools used to quantify parameters such as deformation under load, thermal resistance, chemical durability, onset of deformation, etc. Many such measurements have something in common with optical analysis of the combustion process: namely, that the measurement/image gathering process is often relatively simple - powerful, accurate and insightful post-processing of the measurement and images gathered is the key to maximising the utility of such measurements. Indeed, as shown in Fig. 10, using what might appear to be rather trivial "photographs" of an element under testing (or a combustion cycle within a cylinder), a number of parameters can be derived via digital post-processing software, such as calculation of temperature, heat flow, strain propagation, flame speed, etc - and even the derivation of the concentration of pollutants (e.g. soot, via two-colour pyrometry) [41].

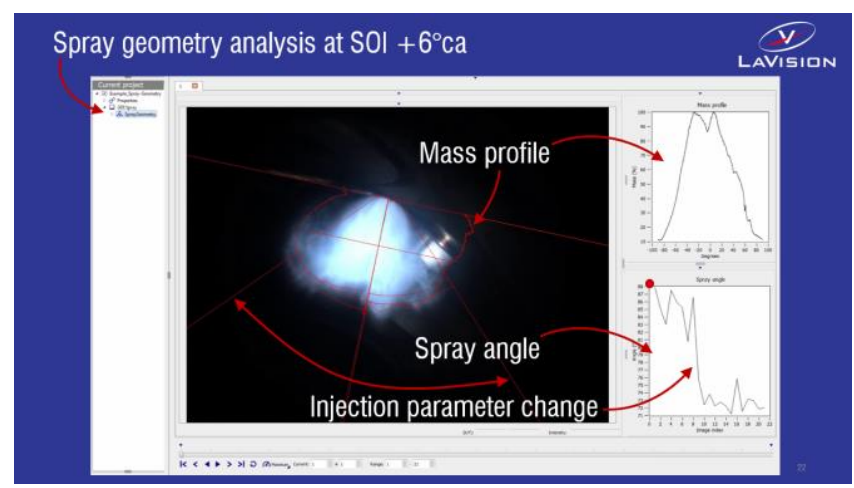

Fig. 10. Computer processing of an image to extract quantitative data on the physicochemical processes captured in the photograph [41]

\section{4. $4^{\text {th }}$ session - Fuel development and its impact on engine technology}

Dr. Christopher Kolodziej (Argonne National Laboratory, USA) gave a presentation on the well-known (but not always widely understood) subject of knock resistance characteristics of liquid fuels. One of the main parameters determining whether a fuel is suitable for use in SI engines is its octane number, necessarily determined according to a standardised method. This parameter is used to define and compare fuels - and to control the quality of fuels sold for public use. The actual knock resistance of a given fuel depends on many factors, not least of which is the test method used - hence the well-known RON-MON difference, with this difference commonly termed sensitivity. A significant consideration is the fact that the knock resistance varies with $\lambda$ and - significantly - fuels are not RON tested at lambda 1 (i.e. stoichiometric conditions), at least not according to standard procedures. Furthermore, there are significant differences between RON method and modern SI engines. A range of experimental work was undertaken to characterize the difference between two knock intensity measurement methods and to identify the effect of $\lambda$ on a fuel's octane rating behaviour. A range of fuels were investigated, which showed variable, $\lambda$-specific behaviour, as shown in Fig. 11; for example, ethanol strongly reduced the maximum amplitude of pressure oscillations under rich conditions. There are certain contradictors trends and tradeoffs. Because of this complex behaviour, use of alternative procedure more reflective of the characteristics and typical operation conditions of modern engines provide a more useful and complete picture of the real knocking tendency (and knock resistance) of a given fuel or fuel blend [42].

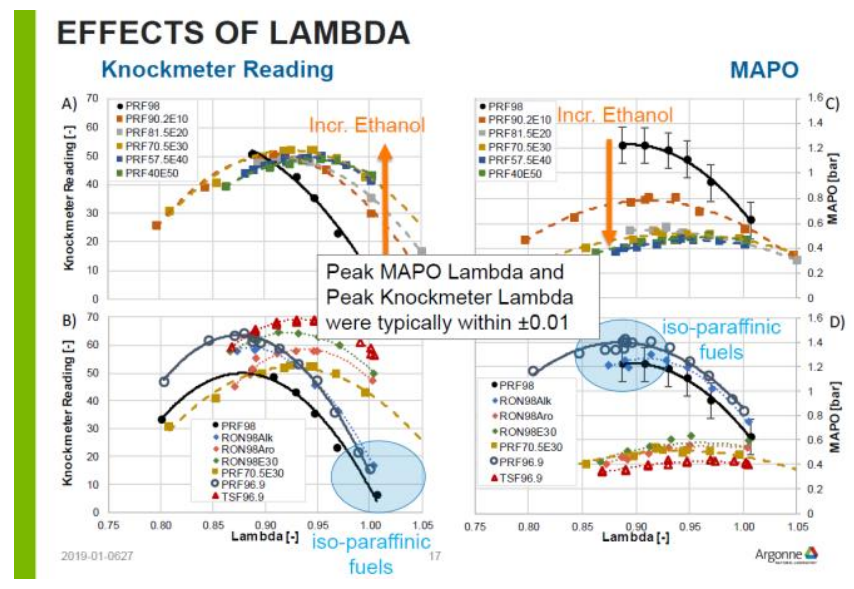

Fig. 11. Knock characterisation of a range of fuels for a range of lambda values [42]

Dr. Tadeu Cordeiro de Melo (Petrobras, Brazil) gave a presentation on the subject of renewable fuels for diesel engines. Motivated by sustainability concerns, increasing attention has been paid to renewable fuels. Biocomponents for use in compression ignition engines are known as biodiesel, which are in widespread use in many markets. The proportion of biodiesel in blends approved for sale in brazil is high compared to other markets - but there are plans to possibly move to even higher levels ( $15 \%$ biodiesel). In light of this, quantifying the impact of such levels of bio- 
components on exhaust emissions is a priority. Testing was carried out to quantify the emissions impact of using such blends on several engines, with the test blends containing soy- and tallow-based biocomponents. The overall literature consensus was confirmed by this work - generally speaking, there were modest reductions in particulate emissions (although levels were sometimes unchanged); $\mathrm{NO}_{\mathrm{x}}$ generally increased somewhat (although levels were unchanged in one case). These findings have obvious implications for the exhaust aftertreatment of such engines running on such blends, and therefore further work on that subject is recommended [43].

Dr. Cecile Pera (at the time an employee of Convergent Science, Austria) spoke about computational fluid dynamics (CFD) and the role it plays in research on combustion engines and closely related topics. Combustion systems in general, and especially modern vehicular powertrains, are characterised by a large number of variables and parameters. Continuing development towards higher efficiency, reduced pollutant formation, extended durability, etc requires quantitative investigation of the impact of varying these parameters. In the case of vehicular powertrains, fuel, lubricant and aftertreatment systems must be included in the overall system-level optimization effort. The sheer number of parameters to be investigated, as well as the fact that much of the low-hanging fruit has already been plucked, has vastly increased the scale and overall complexity of such optimization tasks and computational fluid dynamics (CFD) is an essential tool in this area. CFD is of high utility in tackling essentially all of the challenges currently faced by ICE, and can do so in an interconnected and holistic fashion. Modelling of relevant phenomena often involves consideration of the interactions between matter in three different states, requiring complex physical models of appropriate resolution. Recent advances mean that pollutant formation can be modelled with high accuracy; aftertreatment system functionality may also be modelled, for which parametrised chemical models must obviously be included in order to accurate predict system-level behaviour. Highfidelity simulations are not restricted to modelling the transfer of matter (i.e. mass) - the flow of heat and other quantities such as the frictional forces resulting from reciprocal motion can also be computed. CFD lends itself to investigation of disruptive technologies for use in multiple sectors and to work on new (or revisited) concepts for engine hardware, as well as modified fuels and engine-fuel combinations [44].

Dr. Hu Li (University of Leeds, UK) gave a presentation on biofuel options for Diesel engines and their impact on emissions. The desire to improve the life-cycle performance of fuels used in road transport, as well as general sustainability concerns and an overall drive to reduce pollutant emissions, has led to demand for drop-in biofuels which can be blended into fossil diesel in varying proportions. Fatty acid methyl esters (FAME) have been very well-studied in this context; a newer research direction concerns the use of GTL (Gas to Liquid) and HVO (Hydrotreated Vegetable Oil). Both those fuel types show promise as fuels with good performance in terms of overall carbon intensity and pollutant formation during combus- tion. Differences in the physiochemical properties of GTL and HVO cause significant differences for various phenomena in terms of the combustion process (e.g. ignition delay, in-cylinder pressure) and thereby cause differences in pollutant formation - it is especially important to identify optimal blend levels, since trends are not always linear with respect to increasing blend content and so-called "bounceback" effects have been identified. Furthermore, for engines used in applications characterised by transient operation, such as road transport, it is vital to investigate performance over a wide range of operating conditions. Such investigations have revealed GTL and HVO to be advantageous from many points of view, including the reduced formation of $\mathrm{NO}_{\mathrm{x}}$ and $\mathrm{PN}$ observed with those fuel types [45].

Yuri Kroyan (Aalto University, Finland) gave a presentation covering recent efforts to model the effect of fuel properties on end-use engine performance. As was also noted by other presenters, the implementation of renewable fuels for transportation is becoming a very important step in the reduction of the sector's carbon footprint. The effective solution for GHGs reduction is the substitution of fossil fuels used in the current fleet by fuels produced from renewable sources such as biofuels. Work has been conducted to investigate how alternative fuel properties affect engine performance and greenhouse gases (GHG) emissions of the current fleet of light-duty vehicles. Based on the experimental results, data-driven black-box modelling has been applied to develop two models, one for spark-ignition (SI) and the second for compression-ignition (CI) unmodified engines. The multiple independent variables of the models (inputs) are represented by fuel properties, whereas single dependent variable (output) stands for fuel consumption (FC) over driving cycles such as Worldwide harmonized Light-duty Test Cycle (WLTC) or New European Driving Cycle (NEDC). Both input and outputs are described by percentage changes relative to the standard fossil-based fuel, gasoline for SI and diesel for CI engines. The chosen modelling methodology is based on multilinear regression. Additionally, quantitative analysis was performed in order to achieve the final state of inputs, significance level below $5 \%$. In both cases, coefficients of determination (R-squared) turned out to be relatively high for the SI case: 0.99; and 0.97 for the CI case. The model for SI engines represents how fuel consumption is affected by the research octane number (RON), density, net calorific value volume based (NCV vol.) and oxygen content based $\left(\mathrm{O}_{2}\right)$. Whereas the model for the CI part reveals density, cetane number $(\mathrm{CN})$ and net calorific value mass based (NCV mass) impact on FC. Developed models represent the end-use performance of alternative fuels and are dedicated to supporting decision-makers and accelerating the commercialization of transport biofuels [46].

\section{5. $5^{\text {th }}$ session - Testing requirements/methodologies - impact on powertrain development}

David Miller (3DATX, USA) gave a wide-ranging presentation on how portable emissions measurement systems can meet the industry's needs regarding development of powertrains for various applications. The key engine development trend at the time of writing and in recent years is the simultaneous reduction of both fuel consumption and 
regulated emissions. Both those aspects (FC/emissions) have been subject to revelations and concerns that much of the progress has been only on paper, rather than delivering real benefits under actual conditions of use. While fuel consumption automatically measured by all modern vehicles and instantaneous and accrued information available to the driver, emissions of regulated pollutants under in the real world under normal operating conditions were not known until the advent of PEMS. As such, based on the fact that a PEMS is much smaller, cheaper and easier to obtain than a full emissions laboratory with chassis dynamometer, PEMS represents an opening up of the field, as it allows parties who otherwise would not have been able to perform emissions testing to perform tests under real-world conditions (normal or non-normal). PEMS is required for legislative purposes (HD ISC in the EU, HD ISC in the EU, LD type approval and market surveillance in the EU), but may also be used by a range of parties for a wide range of purposes and test types. The very wide range of applications equipped with ICEs is starting to cause the PEMS market to deliver specialised devices - in many situations, a full legislation-compliant PEMS is simply not necessary. In the same way that computers have reduced their size and weight by orders of magnitude while increasing computing power, PEMS designs are evolving - the term 'portable' can be subject to many interpretations, but some systems can be safely lifted by one person and even transported in an aircraft as hand-baggage. Making use of such downsized, simplified systems has obvious financial benefits, but can also increase the availability of required data and thereby reduce the so-called "PEMS bottleneck" (which particularly affects the LD sector, but is also present in other sectors). Four categories of PEMS equipment can be defined, ranging from fully legislative to high downsized nanoPEMS, each with specific advantages in certain contexts, as shown in Fig. 12. A key difference between the USA and EU is that the former has no defined specification for LD PEMS. Unsurprisingly, simplified systems of lower cost have to trade-off some accuracy, but if the correlation to official measurements is well-known and closely constrained, then the post-processed data generated by such devices can be acceptable for most purposes [47].

\section{miniPEMS - Pluses and Minuses:}
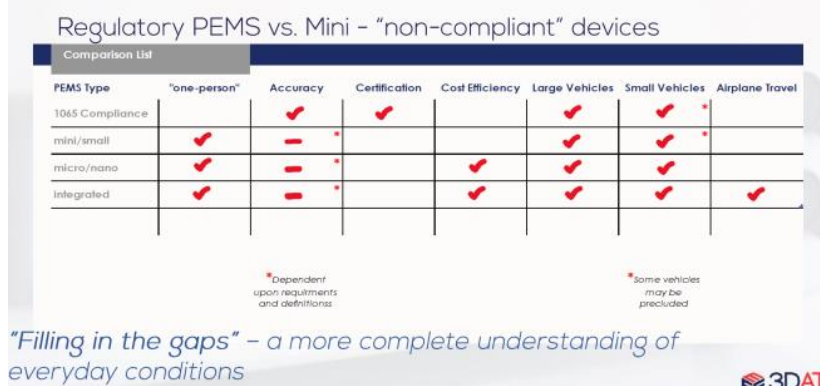
everyday conditions

Fig. 12. Matrix of suitability and applicability of different types of PEMS for testing emissions from combustion engines under real operating conditions [47]

Dr. Xin Wang (Beijing Institute of Technology, China) gave a presentation on RDE requirements in China. While
RDE is the term used in the EU, PEMS testing traces its origins to the USA. Recently, a number of Asian countries have announced their intention to introduce RDE-like testing. One such country is China, a highly populous and rapidly developing country facing well-known air quality challenges. Chinese RDE is inspired by - and largely based on - the EU RDE procedure, but features some important differences. Firstly, the conformity factors are numerically higher than the values currently mandated in in the EU, taking values of 2.1 for $\mathrm{NO}_{\mathrm{x}}$ and $\mathrm{PN}$ (for the time being). As a related point, it should be noted that the base emissions limits for China 6 are fuel-neutral, with no Diesel $\mathrm{NO}_{\mathrm{x}}$ "allowance". Secondly, the moving average window method is used for the final calculation of emissions results (while EU legislation has dropped this requirement). Finally, Chinese topography mean that large numbers of vehicles are operated at high altitudes - and so China has an additional category of boundary condition called "Further extended altitude condition" for altitudes between 1300 and $2400 \mathrm{~m}$ above sea level. This last point represents a significantly more demanding aspect of Chinese RDE legislation compared to EU RDE legislation. The emissions excess allowed in this category is relatively large (the correction factor by which results are divided is 1.8). The fact that more than $25 \%$ of Chinese territory (and thus a large number of major roads) lie at altitudes $>1000 \mathrm{~m}$ and that, in contrast, there are few major roads in Europe at altitudes $>1300$ m explains this divergence from the EU RDE legislation. Emissions control at elevated altitudes is sometimes (but not necessarily always) challenging; however, at present limited data are available as the vast majority of powertrain research is conducted at low altitudes. A variety of effects can complicate engine operation and worsen emissions at high altitude, but these may not always translate into increased exhaust emissions if the efficiency of the aftertreatment system remains high, as shown in Fig. 13. The requirement to meet emissions limits over such a wide altitude range (relatively wide in the case of the EU; very wide in the case of China) complicates development and pre-certification testing [48].

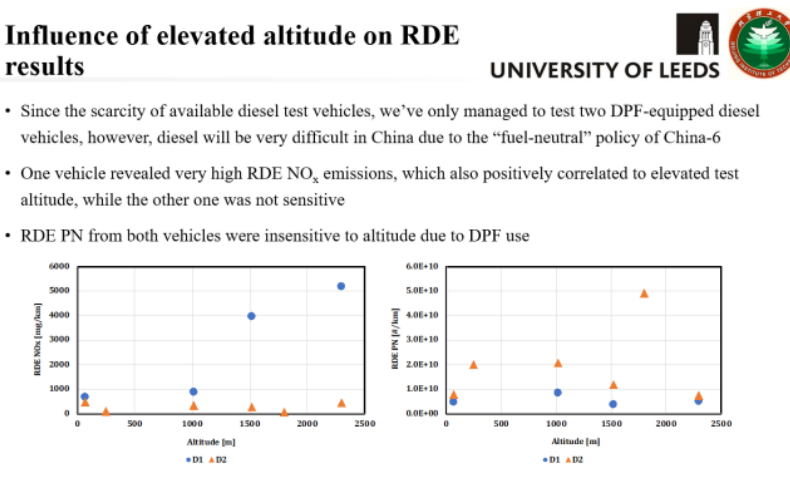

Fig. 13. Exhaust emissions of $\mathrm{NO}_{\mathrm{x}}$ and $\mathrm{PN}$ obtained under Chinese RDE conditions (included extended altitude) [48]

Daisy Thomas (University of Leeds, UK) reported on her work on particulate emissions from modern powertrains (in the form of RDE testing of a hybrid passenger car). Hybrid powertrains continue to attract significant interest and represent a growing market share of new vehicles, not 
only in the context of reducing fuel consumption and $\mathrm{CO}_{2}$ emissions, but also due to their potential to reduce exhaust emissions of regulated (and unregulated) harmful compounds. The vast majority of hybrid powertrains feature a spark ignition engine as their combustion engine component. In such a configuration, the spark ignition may start frequently and run for short periods of time, with impacts on exhaust emissions. Particulate from SI engine with indirect injection have traditionally been judged to be low and virtually ignored (current EU legislation does not require PM or PN measurements for such engines, whether part of a hybrid powertrain or not). SI engines with indirect injection produce particulate of relatively low number and very small size, making gravimetric emissions extremely low. However, the particle number emissions are measurable and in the special case of hybrid powertrains, the question arises as to what the impact of repeated starts and interrupted engine warmup has on PN emissions from vehicles fitted with such powertrains under real driving conditions. Similar vehicles featuring SI engines with direct injection are subject to PM and PN limits in the EU, with PN assessed during real driving conditions via RDE tests. A series of tests was carried out under normal driving conditions (RDE-compliant) using PEMS to measure PN and gaseous emissions. Both vehicles showed significant peaks resulting from the engine on events which occurred during the cycle; despite the fact that the combustion engine was off for a significant portion of the test, the final PN results were judged to be higher than for similar vehicles with conventional powertrains under the same driving conditions. Every engine start, even for a warm/hot engine, caused a spike in PN emissions, although the size of the particles (and therefore the hazard they pose to human health) changed significantly once the engine had warmed up, as shown in Fig. 14. The ambient temperature, hybrid battery state of charge and powertrain control strategy all have a significant impact on the PN results [49].

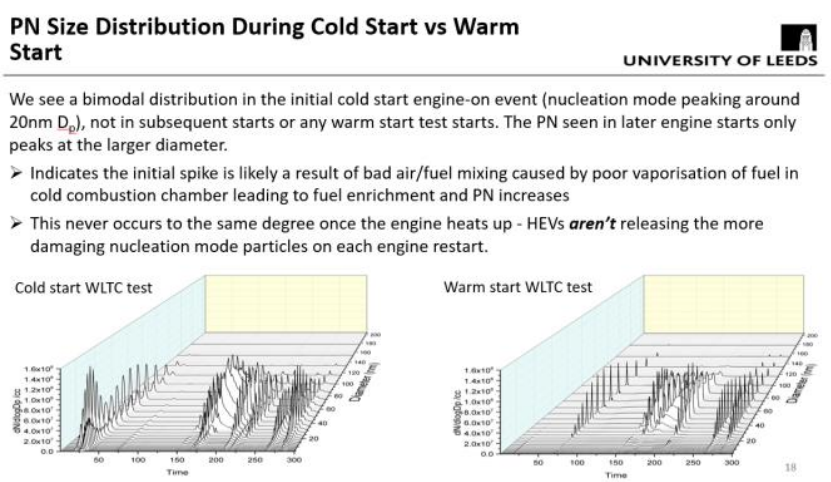

Fig. 14. Time-resolved PN size distribution profile for a hybrid vehicle running over the WLTP from cold and warm start conditions [49]

Maciej Jaskiernik (FEV, Poland/Germany) gave a presentation covering simulation of oil flow. The trend for reducing emissions and increasing fuel efficiency is not exclusive to the on road sector (LD/HD) - marine engines, inter alia, are also under pressure to achieve reductions. Changes made to engine hardware to achieve the required effects have increased parameters such as peak, pressure,
BMEP, thermal load and mechanical load on bearings. In order to maintain reliability and durability, changes to engine hardware must be carefully considered and investigated. The vast number of parameters and very wide range of potential operating conditions means that the research effort involved in such investigations is immense. For that reason, simulation can be an attractive option, reducing the development cost and helping to meet tight deadlines. One area where such an approach has been adopted is in modelling the oil flow through the connecting rod to the piston cooling channels in medium speed engines. Self-evidently, such simulation is a complex CFD task. By making some simplifications and deriving equations to describe the motion in terms of translation, angular acceleration and rotation and adding CFD models to describe oil flow and sloshing, it is possible to examine the oil flow through the crank mechanism. Differences from preliminary calculations can be identified and attributed to various physical effects (including oil sloshing) [50].

The final presentation was unfortunately not delivered, due to the speaker's unforeseen inability to attend the Congress [51].

\section{Summary and overall conclusions}

Despite ongoing changes (for example, powertrain electrification and historically low fuel consumption in many new passenger cars) and the relatively low price of oil, there is continuing pressure to make a partial - or even perhaps full - switch to alternative fuels and low carbon or even carbon-free fuels [52]. The process of substituting mineral fuels with biofuels continues to make slow, uneven progress - recently, the USA allowed the sale of E15 (i.e. $15 \%$ ethanol content by volume) during the summer throughout the USA. In the EU, all Diesel sold contains biocomponents $(83 \%$ of all Diesel sold containing FAME at concentrations $\leq 7 \%), 85 \%$ of all gasoline sold in the EU contained ethanol, but the vast majority of ethanol-bearing gasoline contained $\leq 5 \%$ ethanol and some $15 \%$ of all gasoline sold contained no ethanol at all. This means that the overwhelming majority of the fuel (and energy) used for propulsion of road vehicles is derived from crude oil. Currently, interest in HVO is very high, yet sales volumes remain vanishingly small compared to standard B7 diesel.

As the sine qua non of a combustion engine's operation is the combustion event itself, it is important to focus on combustion phenomena and their fundamental causes and practical implications when considering any aspect of the use of conventional vehicles. Even plug-in hybrids and range extended EVs are equipped with a combustion engine which is used for a non-negligible portion of the vehicle's lifetime $[53,54]$; only battery electric vehicles (BEV) with no range extender are completely combustion-free during use [55-57]. Thus, research on combustion itself remains an essential and indispensable part of efforts to improve the environmental performance of vehicles, even (and arguably especially) in the age of powertrain electrification. While hybrid powertrains are normally mentioned first and foremost in the context of reduced fuel consumption $/ \mathrm{CO}_{2}$ emissions, they can also offer significant benefits in terms of reductions of pollutant emissions [49, 53]. Consideration of the above, together with general consumer demands, creates 
a highly demanding environment for engineering work of this type. The increase in the number of degrees of freedom resulting from powertrain hybridisation and adequate consideration of the long-term energy balance under realistic real-world conditions [53] significantly complicates development and optimisation processes. The market currently contains a wider variety of solutions and overall powertrain characteristics than is sometimes assumed (see [54] for a detailed review). This diversity of options, plus the vast scale of a modern electronic powertrain control strategy (calibration), mean that methods and strategies employed in the past are simply no longer viable in some cases. Even purely electric vehicles must also undergo a highly complex process during their development - here again, there is diversity in terms of powertrain characteristics and the market-available solutions of this type (see [57] for a detailed review and [3] for general information and [55] for information on the EU market). Regardless of powertrain type/configuration, in the era of big data, harvesting and processing relevant data, available at high resolution and on a massive scale, are key elements in the powertrain (and indeed vehicle) design and development process [4]. As the range of engine designs, sizes, operating conditions and even fuel types is large, numerical approaches taking advantage of the capabilities of modern computers have evident advantages in terms of the depth and resolution of data they can provide. However, a balanced approach has to be maintained: real-world scenarios (rather than idealised laboratory conditions) must be used as evaluation conditions to ensure that $R \& D$ advances translate into real benefits for society and the environment, while avoiding (or minimising) increased financial costs. For example, continuing efforts to increase the efficiency of conventional combustion engines have made great advances in recent years, yet the operating points at which these highest efficiency level is achieved does not necessary respond to a typical real-world-duty cycle for a passenger car. Indeed, the part load problem continues to be a significant disadvantage and the cause of significant excess fuel consumption, a problem which occurs on a very wide scale. While exhaust emissions at idle are low, pull away and acceleration events, as are inherent in heavy urban traffic continue to account for a very large share of total exhaust emissions. A range of engine redesign options (including, but not limited to, hybridisation) are attractive options to solve this problem [58]. However, the other side of the coin is infrastructure - the road itself and the flow traffic upon it. There appears to be considerable scope to make use of the abundance of electronics in modern vehicles, the ubiquity of the internet [4] and adaptive systems to optimise traffic flow and attempt to increase the mean travel speed, thus reducing journey time and thereby reducing emissions. For full hybrids - especially plug-in hybrids - there may be future requirements for geofencing, whereby the vehicle realises that it is in a designated low emissions zone and limits the use of the combustion engine accordingly. Such discussions extend well beyond powertrain engineering, yet could prove to be deciding factors in the near future regarding the design of automotive propulsion systems, for both light- and heavyduty $[59,60]$.
A very wide range of objects, activities and areas of human endeavour are united by a shared factor: their reliance on combustion engines. In terms of debates on the environmental performance of such units, road transport usually comes to the fore, with a particular focus on passenger cars. While segments and applications can indeed be examined individually, there can be a surprising amount of cross-over and transferability between segments. The use of CNG as fuel has perhaps expanded more slowly (and less widely) than was predicted, but it has made advances in both the light and heavy-duty branches of road transport, among others, presenting many opportunities for mutually beneficial lessons to be learned. The rapid and expansive rollout of SCR in the on-road heavy-duty sector paved the way for implementation in light-duty applications, but heavy-duty SCR was itself built upon the successes of that technology in the power generation sector. Informationsharing between segments, branches and industries is key to progress and can significantly speed up market-ready implementation, while reducing costs. SCR is widely regarded as the best available technology for $\mathrm{NO}_{\mathrm{x}}$ control from leanburning engines of all types; SCR using ammonia as the reducing agent was patented in 1957, yet it took over 60 years for the majority of new passenger cars in the EU running on Diesel to feature SCR aftertreatment. While there are certain important differences between DPFs and GPFs, the rollout of the latter was aided by experience gained from the rollout and gradual optimisation of the former [61, 62].

Legislative requirements are moving away from a vague minimum performance-type structure (i.e. the setting of maximum emissions limits, tested under very well-defined, inflexible test conditions) towards a more comprehensive, multipronged approach in which limits not only have to be met under a wide range of conditions (i.e. during RDE/ISC testing), but certain technical decisions must also be revealed and justified (auditing of emissions control strategies). The number of pollutants for which legal limits are set is also set to expand somewhat, although some pollutants can be controlled indirectly, i.e. by limiting compounds with which they share a strong correlation in terms of exhaust emissions levels.

Planned emission standards for LDV and HDV for the future (Euro 7/VII regulations) are as follows:

- Pollutant emissions to be considered along with GHG emissions (perhaps via $\mathrm{CO}_{2}$-equivalent values being applied to $\mathrm{CH}_{4}$ and $\mathrm{N}_{2} \mathrm{O}$, both of which are powerful GHG),

- Low ambient temperature cold start test using the WLTP methodology,

- Currently unregulated emissions may also be considered (GHG: $\mathrm{N}_{2} \mathrm{O}, \mathrm{CH}_{4}$; harmful species $\mathrm{NH}_{3}, \mathrm{NO}_{2}$, broader measurement of particulates: PN $10 \mathrm{~nm}$ ),

- Fuel- and technology-neutral regulations and emissions; possible setting of equivalent (not identical) emissions limits for LD and HD,

- A move from onboard diagnostics of emissions malfunctions to continuous on-board monitoring of emissions (i.e. $\mathrm{OBD} \rightarrow \mathrm{OBM}$ ). 
While the majority of the most recent legislative developments have been applicable to light-duty vehicles, further changes are underway (or will be soon confirmed) in other sectors, even those far removed from roads (like the marine sector). The setting of precedents in one sector or geographic area is highly significant, as this can then serve as a justification for the setting of equivalent (or even identical) limits in other jurisdictions and other sectors. While the main focus of powertrain development is currently on emissions reduction (achieved by means emphatically not limited to aftertreatment and hybridisation), such efforts are underpinned by core research on "traditional" engine fundamentals such as combustion, thermodynamic considerations, gas kinetics, tribology/lubrication, etc. By bringing together progress and advances in many areas, powertrain concepts may be devised which provide genuine benefit for users, society and indeed the environment. Future congresses to be organised by PTNSS (and its various partners) will aim to continue to facilitate the exchange of information and ideas that is required for the efforts discussed in this paper.

\section{Bibliography}

[1] BP Energy Outlook, 2020 edition. https://www.bp.com/

[2] NEUGEBAUER, S. Technological scenarios for the decarbonization of road transport. In "Connectivity-Key to future emission and consumption reduction? Proceedings of the Vehicle and Powertrain" 30th International AVL Conference "Engine \& Environment", Graz, Austria, 7-8 June 2018.

[3] CUI, H., HALL, D., LUTSEY, N. Update on the Global Transition to Electric Vehicles Through 2019. ICCT. Washington, DC, USA, 2020.

[4] ABE, S. The future direction of the electrified vehicle utilizing of big data. Proceedings "Connectivity - The key to future emission and consumption reduction? In: Vehicle and Powertrain" 30th International AVL Conference "Engine \& Environment", Graz, Austria, 7-8 June 2018.

[5] SUAREZ-BERTOA, R. Preparing new European emission standards post-Euro 6, 3rd China-EU Workshop on Emissions Standards and Regulations. Xi'an, China, October 911, 2019.

[6] EUROPEAN COURT OF AUDITORS. Air pollution: Our health still insufficiently protected. Special Report EN No 23/2018. EU Publications Office. Luxembourg 2018.

[7] WINKLER, S.L., ANDERSON, J.E., GARZA, L. et al Vehicle criteria pollutant $\left(\mathrm{PM}, \mathrm{NO}_{\mathrm{x}}, \mathrm{CO}, \mathrm{HCs}\right)$ emissions: how low should we go? Climate and Atmospheric Science. 2018, 1, 26. https://doi.org/10.1038/s41612-018-0037-5

[8] VEHICLE EMISSIONS CONTROL CENTRE (CHINA). Real Driving Emissions (RDE) Technical Specification \& Test Study of Light-duty Vehicle in China. 3rd China-EU Workshop on Emissions Standards and Regulations. Xi'an, China, October 9-11, 2019.

[9] RODRIGUEZ, F. Post-Euro 6/VI standards: An opportunity for international harmonization. 3rd China-EU Workshop on Emissions Standards and Regulations. Xi'an, China, October 9-11, 2019.

[10] MERKISZ, J., PIELECHA, J., BIELACZYC, P. et al. Analysis of emission factors in RDE tests as well as in NEDC and WLTC chassis dynamometer tests. SAE Technical Paper 2016-01-0980, 2016. https://doi.org/10.4271/2016-01-0980

[11] GIECHASKIEL, B., LAHDE, T., SUAREZ-BERTOA, R. et al. Particle number measurements in the European legislation and future JRC activities. Combustion Engines. 2018, 174(3), 3-16. https://doi.org/10.19206/CE-2018-301

[12] BIELACZYC, P. Particulate number (PN) \& gaseous emissions in the EU automotive emissions context. Expert Panel Discussion EU/China Emissions Regulations. SAE 2019 WCX World Congress. Detroit, MI, USA.

[13] GIECHASKIEL, B., LAHDE, T., CLAIROTTE, M. et al Post Euro 6/VI activities focusing on particle number. SAE 2019 WCX World Congress. Detroit, MI, USA. https://doi.org/10.13140/RG.2.2.26039.37286
[14] GIECHASKIEL, B., MAMAKOS, A., WOODBURN, J. et al. Evaluation of a $10 \mathrm{~nm}$ Particle Number Portable Emissions Measurement System (PEMS). Sensors. 2019, 19, 5531. https://doi.org/10.3390/s19245531

[15] BIELACZYC, P. Global development of emissions reduction strategies from light-duty vehicles. IOP Conf. Series: Earth and Environmental Science. 2019, 214, 012139, IOP Publishing. https://doi.org/10.1088/1755-1315/214/1/0121

[16] BIELACZYC, P., WOODBURN, J., Current directions in LD powertrain technology in response to stringent exhaust emissions and fuel efficiency requirements. Combustion Engines. 2016, 166(3), 62-75. https://doi.org/10.19206/CE-2016-341.

[17] MCKINSEY \& COMPANY. The future of mobility is at our doorstep. Compendium. 2019/2020.

[18] BIELACZYC, P., WOODBURN, J. Powertrain development for low-to-zero emissions and efficient energy usage the Industry Session held during $5^{\text {th }}$ PTNSS Congress on Combustion Engines. Combustion Engines. 2013, 155(4), 75-79.

[19] BIELACZYC, P., WOODBURN, J., GANDYK, M. Trends in automotive emissions, fuels, lubricants, legislation and test methods - a global view, with a focus on the EU \& US - Summary of the 5th International Exhaust Emissions Symposium (IEES). Combustion Engines. 2016, 166(3), 7682. https://doi.org/10.19206/CE-2016-342

[20] BIELACZYC, P., WOODBURN, J. Trends in automotive emission legislation: impact on LD engine development, fuels, lubricants and test methods: a global view, with a focus on WLTP and RDE regulations. Emissions Control Science Technology. 2019, 5(1), 86-98. https://doi.org/10.1007/s40825-019-0112-3

[21] HILL, L. Global trends in emissions legislation. The VIII PTNSS International Congress on Combustion Engines. 1719 June 2019, Krakow, Poland.

[22] BIELACZYC, P., KLIMKIEWICZ, D., WOODBURN, J. et al. Exhaust emission testing methods - BOSMAL's legislative and development emission testing laboratories. Combustion Engines. 2019, 178(3), 88-98. https://doi.org/10.19206/CE-2019-316

[23] PAJDOWSKI, P., WOODBURN, J., BIELACZYC, P. et al. Development of RDE test methodology in light of Euro 6d emissions limits. Combustion Engines. 2019, 178(3), 274282. https://doi.org/10.19206/CE-2019-348

[24] BIELACZYC, P. Global trends in vehicular emissions regulations, current "hot topics" and their impact on powertrain technology - introduction to the subject. VIII International PTNSS Congress on Combustion Engines. 17-19 June 2019, Krakow, Poland.

[25] VALVERDE-MORALES, V. Overview of the light-duty vehicles tailpipe emissions regulations in the European Un- 
ion: status and upcoming type-approval and market surveillance schema. Combustion Engines. 2020, 180(1), 3-7. https://doi.org/10.19206/CE-2020-101

[26] JOSHI, A. Review of vehicle engine efficiency and emissions. SAE International Journal of Advances and Current Practices in Mobility. 2019, 1(2), 734-761. https://doi.org/10.4271/2019-01-0314

[27] JOSHI, A. Overview of technologies for near-zero tailpipe emissions from light- and heavy-duty vehicles. The VIII PTNSS International Congress on Combustion Engines. 1719 June 2019, Krakow, Poland.

[28] MERKISZ, J. Development trends in road transport powertrains. The VIII PTNSS International Congress on Combustion Engines. 17-19 June 2019, Krakow, Poland.

[29] FRIEDL, H., FRAIDL, G., KAPUS, P. Highest efficiency and ultra-low emission - internal combustion engine 4.0. Combustion Engines. 2020, 180(1), 8-16. https://doi.org/10.19206/CE-2020-102

[30] ENGELJEHRINGER, K. LD vehicle emission challenge from legislation to testbed. The VIII PTNSS International Congress on Combustion Engines. 17-19 June 2019, Krakow, Poland.

[31] MASON, A., ROBERTS, P., WHELAN, S. et al. RDE plus - a road to rig development methodology for complete RDE compliance: road to chassis perspective. SAE International Journal of Advances and Current Practices in Mobility. 2020, 2(3), 1361-1381. https://doi.org/10.4271/2020-01-0378.

[32] WHELAN, S., ROBERTS, P. Meeting the demands of future powertrain test \& development with an integrated RDE+ road-to-rig approach. The VIII PTNSS International Congress on Combustion Engines. 17-19 June 2019, Krakow, Poland.

[33] ALONSO BAEZ, M. Investigation of the mechanism of the soot in oil contamination: overtaking the limits of the combustion. The VIII PTNSS International Congress on Combustion Engines. 17-19 June 2019, Krakow, Poland.

[34] ROLANDO, L., ZANELli, A., MILLO, F. Potential of electric supercharging for performance and fuel economy enhancement of passenger car gasoline engines. The VIII PTNSS International Congress on Combustion Engines. 1719 June 2019, Krakow, Poland.

[35] PERUJO, A., BONNEL, P., GIORIA, R. et al. Large and small engines: overview of the heavy-duty vehicles and nonroad mobile machinery tailpipe emissions regulations in the EU. The VIII PTNSS International Congress on Combustion Engines. 17-19 June 2019, Krakow, Poland.

[36] AOYAGI, Y. Measurement of flame temperature and soot amount for effective $\mathrm{NO}_{\mathrm{x}}$ and $\mathrm{PM}$ reduction in a heavy-duty diesel engine. Combustion Engines. 2019, 179(4), 32-39. https://doi.org/10.19206/CE-2019-405

[37] AOYAGI, Y. Effective $\mathrm{NO}_{\mathrm{x}}$ and PM reduction by means of flame temperature measurement in a single cylinder diesel engine. The VIII PTNSS International Congress on Combustion Engines. 17-19 June 2019, Krakow, Poland.

[38] NAKASHIMA, K., UCHIYAMA, Y. Experimental development of apparatus to measure piston assembly friction in an eco-mileage vehicle engine. Combustion Engines. 2019, 177(2), 55-59. https://doi.org/10.19206/CE-2019-210

[39] GOLINI, S. NG engines as a means for an increasingly sustainable powertrain. The VIII PTNSS International Congress on Combustion Engines. 17-19 June 2019, Krakow, Poland.

[40] KINNUNEN, T. Engine-integrated off-road stage-V aftertreatment system. The VIII PTNSS International Congress on Combustion Engines. 17-19 June 2019, Krakow, Poland.
[41] DEPPE, J. Turn-key „Inspex” systems for industries to quantify optically spray \& combustion phenomena and to analyze material characteristics by DIC. The VIII PTNSS International Congress on Combustion Engines. 17-19 June 2019, Krakow, Poland.

[42] KOLODZIEJ, C., ROCKSTROH, T., HOTH, A. et al. Gasoline composition effects on knocking characteristics between the CFR RON test engine and a modern GDI engine. The VIII PTNSS International Congress on Combustion Engines. 17-19 June 2019, Krakow, Poland.

[43] CORDEIRO DE MELO, T., GOMES, H.O., MOREIRA, M.F. et al. Influence of biodiesel blends on the emissions of different engine technologies. The VIII PTNSS International Congress on Combustion Engines. 17-19 June 2019, Krakow, Poland.

[44] PERA, C. How engine technology and fuel proprieties can be optimised thanks to CFD. The VIII PTNSS International Congress on Combustion Engines. 17-19 June 2019, Krakow, Poland.

[45] LI, H., WU, Y., ANDREWS, G. Combustion and emissions of alternative fuels in a diesel engine. The VIII PTNSS International Congress on Combustion Engines. 17-19 June 2019, Krakow, Poland.

[46] KROYAN, Y., WOJCIESZYK, M., LARMI, M. et al. Modeling the effect of fuel properties on end-use engine performance. The VIII PTNSS International Congress on Combustion Engines. 17-19 June 2019, Krakow, Poland.

[47] BERRY, M., MILLER, D. The democratization of vehicle emissions testing. The VIII PTNSS International Congress on Combustion Engines. 17-19 June 2019, Krakow, Poland.

[48] WANG, X. RDE regulation and practice in China. The VIII PTNSS International Congress on Combustion Engines. 1719 June 2019, Krakow, Poland.

[49] THOMAS, D., LI, H., WANG, X. et al. Tailpipe exhaust particle size distribution from a hybrid car. The VIII PTNSS International Congress on Combustion Engines. 17-19 June 2019, Krakow, Poland.

[50] JASKIERNIK, M., BUCZEK, K., WALKOWIAK, J. Simulation of the oil supply through the connecting rod to the piston cooling channels in medium speed engines. Combustion Engines. 2020, 180(1), 25-30. https://doi.org/10.19206/CE-2020-104

[51] BUSTIN, L. Variable partial flow dilution and conditioning system for TSI engine exhaust particle sizer. The VIII PTNSS International Congress on Combustion Engines. 1719 June 2019, Krakow, Poland.

[52] PALENCIA, J.C.G., NGUYEN, V.T., ARAKI, M. et al. The role of powertrain electrification in achieving deep decarbonization in road freight transport. Energies. 2020, 13, 2459. https://doi.org/10.3390/en13102459

[53] PIELECHA, J., MERKISZ, J., BIELACZYC, P. et al. Gaseous emissions from a hybrid vehicle and a non-hybrid vehicle measured under real driving conditions via PEMS. FISITA Technical Paper F2018/F2018-PTE-266.

[54] ZHUANG, W., LI (EBEN), S., ZHANG, X. et al. A survey of powertrain configuration studies on hybrid electric vehicles. Applied Energy. 2020, 262, 114553. https://doi.org/10.1016/j.apenergy.2020.114553

[55] HALL, D., WAPPELHORST, S., MOCK, P. et al. European Electric Vehicle Fact Book 2019/2020. ICCT. Washington, USA 2020.

[56] BIELACZYC, P. Global trends in electrified powertrains challenges. in testing methods. Polish Conference on Hydrogen Energy and Technology (PCHET 2020). 2223.09.2020, Cluster of Hydrogen Technologies, Gdansk, Poland. 
[57] LI, Z., KHAJEPOUR, A., SONG, J. A comprehensive review of the key technologies for pure electric vehicles. Energy. 2019, 182, 824-839. https://doi.org/10.1016/j.energy.2019.06.077.

[58] GÓMEZ VILCHEZ, J.J., JOCHEM, P. Powertrain technologies and their impact on greenhouse gas emissions in key car markets. Transportation Research Part D: Transport and Environment. 2020, 80, 102214 https://doi.org/10.1016/j.trd.2019.102214

[59] SMALLBONE, A., JIA, B., ATKINS, P. et al. The impact of disruptive powertrain technologies on energy consumption and carbon dioxide emissions from heavy-duty vehicles. Energy Conversion and Management. 2020, 6, 100030. https://doi.org/10.1016/j.ecmx.2020.100030

Piotr Bielaczyc, DEng., FSAE - Scientific Secretary, BOSMAL Automotive Research and Development Institute Ltd in Bielsko-Biala, Poland

e-mail:piotr.bielaczyc@bosmal.com.pl
[60] KOERFER, T. Hybridized diesel powertrains for LCV applications to meet the Stringent 2025 standards for pollutant- and $\mathrm{CO}_{2}$-emissions. SAE Technical Paper 2020-012252. 2020. https://doi.org/10.4271/2020-01-2252

[61] DZIDA, J., BIELACZYC, P., BRZEŻAŃSKI, M. The variation of functional characteristics of a Euro VI selective catalytic reduction reactor after ageing. SAE Technical $\mathrm{Pa}$ per 2020-01-2205. 2020. https://doi.org/10.4271/2020-01-2205

[62] JOSHI, A. Review of vehicle engine efficiency and emissions. SAE International Journal of Advances and Current Practices in Mobility. 2020, 2(5), 2479-2507. https://doi.org/10.4271/2020-01-0352.

Joseph Woodburn, MSci - Exhaust Emission Laboratory, BOSMAL Automotive Research and Development Institute Ltd in Bielsko-Biała, Poland

e-mail: joseph.woodburn@bosmal.com.pl

Ameya Joshi, DEng. - Director of Emerging Technologies, Corning Incorporated, USA

e-mail:joshia@corning.com 